\title{
Did the Great Recession Downsize Immigrants and Native-Born Americans Differently? Unemployment Differentials by Nativity, Race and Gender from 2007 to 2013 in the U.S.
}

\author{
Sharron Xuanren Wang * and Arthur Sakamoto \\ Department of Sociology, Texas A\&M University, 4351 TAMU, College Station, TX 77843-4351, USA; \\ asakamoto@tamu.edu \\ * Correspondence: xw2683@tamu.edu; Tel.: +1-979-845-5133; Fax: +1-979-862-4057 \\ Academic Editor: Martin J. Bull
}

Received: 21 June 2016; Accepted: 9 September 2016; Published: 14 September 2016

\begin{abstract}
We use data from the Current Population Survey from 2007 and 2013 to investigate demographic differentials in unemployment during the Great Recession in the U.S. Although our analysis is primarily exploratory and descriptive, our major research objective is to illuminate the unemployment differential between the foreign born and the native born. The findings indicate that during the height of the Great Recession, the foreign born had higher unemployment rates than the native born. However, this differential is statistically explained by their observed characteristics, such as race/ethnicity, gender, age and education. With the net of those variables and a few other demographic covariates, foreign born workers as an overall group actually had somewhat lower chances of being unemployed than native born workers. This finding is discussed in terms of the selectivity of immigrant workers and the possibility that they are somewhat more immediately dependent on having a job. After breaking down the foreign born into major racial/ethnic groups, the results suggest that foreign-born blacks and foreign-born Hispanics are particularly selective with the net of their observed characteristics. The possible sources of such differentials by race/ethnicity and by gender are discussed.
\end{abstract}

Keywords: unemployment; Great Recession; race; ethnicity; immigrants; gender

\section{Introduction}

The last recessionary period in the U.S. began at the end of 2007 and lasted for several years. Its magnitude was quite large by U.S. standards. Now known as the Great Recession, it began with the mortgage lending market and the financial crisis associated with the bursting of the housing bubble. It quickly led to additional financial turmoil in the U.S. and then spread to other parts of the world. The Great Recession ended up being the worst economic crisis in the U.S. since the Great Depression [1].

The Great Recession began impacting the U.S. labor market in 2008. Unemployment rose to levels not seen since the 1930s. In addition, the unemployment duration reached a historic peak. According to the Bureau of Labor Statistics, the annual unemployment rate jumped to $9.3 \%$ in 2009 and $9.8 \%$ in 2010. By traditional U.S. standards, the unemployment rate still remained high at $6.2 \%$ in 2014 [2]. Kochhar et al. [3] reported that about one out of every three adult workers had been unemployed for some period of time during the Great Recession.

The consequences of unemployment are detrimental not only at the societal level, but also at the individual level, including low labor participation rates [1], low rates of reemployment, difficulty finding full-time jobs, earnings losses and reduced productivity in the overall economy [4]. 
Unemployment is typically a central concern for an individual's economic, psychological and social well-being [5]. For example, unemployment has detrimental consequences for one's personal finances, mental health, marital stability and criminal activity [6-9].

Unemployment, like other economic indicators, is known to vary by race/ethnicity [10], as well as by nativity [11]. Unemployment is thus immediately implicated in broader societal patterns of socioeconomic inequalities. Being critically important for almost all groups in American society, unemployment differentials and trends need to be constantly monitored by social scientists. In this regard, one major issue is whether immigrants and the native born fared differently during the economic contraction. The Great Recession provides researchers with a unique opportunity to study demographic differentials in unemployment during a major macroeconomic downturn.

\section{Growing Diversity in the American Labor Force}

The American labor force is increasingly characterized by demographic diversity, such as race/ethnicity and gender [12]. Racial/ethnic minorities and women often face obstacles in obtaining jobs and achieving labor market parity with non-Hispanic white men $[1,13,14]$. Earnings gaps between whites versus African Americans and Hispanics are well known, as are the generally lower wages of women [15].

Regarding nativity, the foreign born (also referred to as "immigrants") have increased their presence in the U.S. labor force [16]. Immigrants currently constitute about $13 \%$ of the total U.S. population, but about $16 \%$ of the labor force. For immigrants, employment in the labor market is generally viewed as "one of the powerful immigrant-integrating institutions" [17]. Employment plays an important role in immigrants' economic integration and social assimilation. Previous research suggests that immigrants have relatively lower unemployment rates, lower wages and higher labor force participation rates compared to the native born [3]. However, immigrants are typically less forceful in using laws to protect their rights in the labor market and are more likely to take jobs in a lower-tier section of the labor market [18].

Immigrants often face various barriers in the U.S. labor market. Compared to the native born, the foreign born frequently lack extensive social networks and are typically unfamiliar with local social norms and culture. Additional limitations may include a lack of English language proficiency and educational credentials from foreign institutions that usually are not recognized in the U.S. labor market $[19,20]$. For these and other related reasons, the foreign born have lower average pay than the native born with the net of age, region of residence and the highest level of education [20,21].

Because immigrants typically provide inexpensive (or at least less expensive) labor, they are often cited as being a significant factor in the widening of earnings inequalities between less educated versus more educated workers [22,23]. However, some prior research casts doubt on the unqualified acceptance of this claim because immigrants do not always compete for the same kinds of jobs preferred by the native born [24,25]. In addition, a large amount of research and data has affirmed that immigrants significantly contribute to the U.S. economy [26]. According to the Fiscal Policy Institute, the contributions immigrants make to the U.S. directly correlate to their share of the population and more specifically to their share of the labor force.

Even though a great deal of previous research finds that immigrants are beneficial to the economy overall, they are often used as a scapegoat for America's labor market problems. Serious investigation about how immigrants have fared in the labor market during the Great Recession is therefore even more needed. For example, Kochhar et al. [3] claim that after the recent recession, immigrants gained jobs while the native born lost them, but this study does not investigate immigrants' unemployment by race/ethnicity or gender. Moreover, simply looking at a particular unemployment rate cannot reveal the whole story of how much the demographic features of immigrants shape their employment opportunities. Understanding unemployment differentials between the foreign born and the native born is not only important from the point of view of descriptive social demography, but also in regard to public policy [27]. 


\section{Research Methods}

In the following, we investigate demographic differentials in unemployment during the Great Recession. While the analysis is primarily exploratory and descriptive, our research focus is on illuminating the unemployment differential between the foreign born and the native born. In doing so, we also consider differentials by race/ethnicity and gender.

\subsection{Data}

We analyze data from the Current Population Survey (CPS) from 2007 to 2013 [28]. The CPS is a well-known household survey conducted jointly by the U.S. Census Bureau and the Bureau of Labor Statistics. We investigate the CPS because it is the main survey that is designed to measure and monitor unemployment trends in the U.S. Although the CPS is fielded monthly, we aggregate the monthly data by year in order to provide annual figures. Data from 2007 to 2013 are studied so as to document the unemployment changes associated with the recessionary period from its onset through its gradual waning.

For our study, the CPS is appropriate because it includes information on demographic and socioeconomic variables, such as age, race/ethnicity, gender, nativity and education. The CPS is nationally representative and available annually using a careful and consistent methodology for the measurement of unemployment. The CPS provides a sample size that is large enough to investigate smaller demographic groups. As is common in studies of unemployment, our sample is restricted to individuals aged 16 to 64 at the time of the survey.

\subsection{Variables}

Unemployment is the dependent variable for our study. In the dataset, persons are classified as unemployed if they were not employed during the reference week, but were available for work (excluding temporary illness) and had made specific efforts to find employment some time during the previous 4 weeks. In addition, individuals are classified as unemployed if they had been temporarily laid off. At the individual level, unemployment is a dichotomous variable, which is coded as 1 for respondents who were unemployed and 0 for respondents who were employed.

Nativity status is an important independent variable in our analysis. This variable is defined as referring to the dichotomous distinction between being native born (i.e., born in the U.S.) versus foreign born (i.e., an immigrant). Native born includes individuals who were born in the U.S. or in U.S. territories, such as Puerto Rico. Persons born abroad of American parents are also classified as being native born. Foreign born is defined as persons who were residing in the U.S. at the time of the survey, but who were born outside the U.S. and U.S. territories to parents who were not U.S. citizens. In our analysis, foreign born includes, but does not distinguish between persons who are U.S. naturalized citizens, U.S. permanent residents, immigrants with valid visas and undocumented immigrants.

Race and ethnicity is defined in terms of 5 mutually-exclusive categories. These include: non-Hispanic whites ( $\mathrm{NH}$-whites) $(\mathrm{N}=4,018,539)$, non-Hispanic African Americans (blacks) $(\mathrm{N}=522,617)$, Hispanics $(\mathrm{N}=720,203)$, Asians $(\mathrm{N}=282,387)$ and others $(\mathrm{N}=125,927)$. While Native Americans and persons with mixed-race identities are included in "other," many foreign-born Mexican immigrants also seem to prefer that racial designation in recent years (Choi, Sakamoto and Powers, 2008). In our detailed analyses, we broke down these racial and ethnic groups by nativity (i.e., whether native born or foreign born), resulting in 10 separate groups.

Additional demographic and socioeconomic variables are also included in our analysis. Age is treated as a continuous variable in years that is often used in labor analyses to indicate years of potential work experience. ${ }^{1}$ Marital status is a dichotomous variable referring to persons who

1 As is commonly done, a quadratic term for age (i.e., age-squared) is also included in the regressions in order to account for the non-linear effect of age. 
are currently married versus unmarried (i.e., single, divorced or widowed). Gender is coded as a dichotomous variable. Education level is measured in terms of several categories for the highest level completed including: less than high school; high school graduate; associate's degree or some college; bachelor's degree; master's degree; Ph.D.; and professional degree (e.g., law or medical). Residential region is based on the standard classification used by the U.S. Census, including the following 9 categories: New England; Mid-Atlantic; East North Central; West North Central; South Atlantic; East South Central; West South Central; Mountain; and Pacific. Class of worker is included as an additional control variable defined as: no previous experience (i.e., new entrants to the labor force without prior paid employment); self-employed; private-sector workers (including for-profit and non-profit businesses); federal government; state government; and local government. These groups are indicated by a set of dichotomous variables.

\subsection{Statistical Methods}

We first present descriptive statistics. Unemployment rates from 2007 to 2013 are shown for the various demographic groups. Unemployment rates refer to the percentage of those in the labor force who are without a job but are actively seeking work (i.e., unemployment rate $=$ (number of unemployed)/(total labor force)). We report unemployment rates based on our own calculations using the individual-level CPS data.

We then estimated logistic regression models in order to obtain multivariate effects for the various demographic groups with the net of the control variables, including age, age squared, education, marital status, region and class of work. ${ }^{2}$ We use this set of control variables in order to assess whether the bivariate differentials in unemployment are statistically explained by these covariates. While other control variables could of course be considered, we use this limited set because they are largely exogenous with respect to (i.e., are not themselves caused by) annual fluctuations in unemployment. Because our analysis is primarily descriptive and exploratory, we do not present a strong theoretical justification for this regression specification. However, we generally seek to provide estimates of broad demographic differentials in the overall labor market rather than focusing on specific industries, occupations or metropolitan areas, which may sometimes deviate from the national average. A more detailed analysis is beyond the scope of our research concerns, since workers may change industries and occupations in response to unemployment.

\section{Empirical Results}

\subsection{Descriptive Statistics}

Table 1 shows the descriptive statistics for the independent variables used in our analysis. We computed descriptive statistics for each year of our data from 2007 to 2013. In general, the descriptive statistics for the demographic characteristics did not vary much over these years. Table 1 therefore displays the results for the average across all years. These results pertain to all persons in the labor force including both the employed and the unemployed.

2 In the preliminary analyses, we analyzed additional model specifications. We do not, however, report the results for these other models because they do not differ much from those discussed below. All of our statistics are obtained using STATA, and the regression results are calculated using CPS person weights. 
Table 1. Descriptive statistics for demographic groups averaged across 2007 to 2013.

\begin{tabular}{|c|c|c|c|c|c|}
\hline & NH-Whites & Blacks & Hispanics & Asians & Others \\
\hline Age (mean in years) & 40.95 & 38.66 & 36.68 & 40.04 & 36.62 \\
\hline \multicolumn{6}{|l|}{ Nativity (\%) } \\
\hline Native Born & 94.90 & 87.22 & 43.50 & 22.76 & 93.51 \\
\hline Foreign Born & 5.10 & 12.78 & 56.50 & 77.24 & 6.49 \\
\hline (Total) & $(100.00)$ & $(100.00)$ & $(100.00)$ & $(100.00)$ & $(100.00)$ \\
\hline \multicolumn{6}{|l|}{ Gender (\%) } \\
\hline Male & 53.01 & 46.88 & 59.00 & 53.03 & 51.00 \\
\hline Female & 46.99 & 53.12 & 41.00 & 46.97 & 49.00 \\
\hline (Total) & $(100.00)$ & $(100.00)$ & $(100.00)$ & $(100.00)$ & $(100.00)$ \\
\hline \multicolumn{6}{|l|}{ Marital Status (\%) } \\
\hline Married & 58.00 & 37.43 & 52.39 & 65.52 & 42.08 \\
\hline Not Married & 42.00 & 62.57 & 47.61 & 34.48 & 57.92 \\
\hline (Total) & $(100.00)$ & $(100.00)$ & $(100.00)$ & $(100.00)$ & $(100.00)$ \\
\hline \multicolumn{6}{|l|}{ Education Level (\%) } \\
\hline Less Than High School & 6.27 & 10.21 & 30.90 & 7.35 & 10.69 \\
\hline High School & 47.30 & 57.58 & 47.97 & 31.70 & 54.73 \\
\hline Some College & 10.85 & 9.97 & 7.05 & 7.23 & 10.92 \\
\hline Bachelor's & 23.65 & 15.28 & 10.18 & 32.28 & 16.24 \\
\hline Master's & 8.69 & 5.50 & 2.84 & 14.36 & 5.39 \\
\hline Professional & 1.77 & 0.77 & 0.58 & 2.96 & 1.04 \\
\hline Doctoral & 1.48 & 0.69 & 0.47 & 4.13 & 0.98 \\
\hline (Total) & (100.00) & $(100.00)$ & (100.00) & $(100.00)$ & $(100.00)$ \\
\hline \multicolumn{6}{|l|}{ Region (\%) } \\
\hline New England & 6.13 & 2.36 & 2.29 & 4.39 & 2.95 \\
\hline Mid-Atlantic & 13.52 & 13.96 & 11.26 & 16.03 & 6.61 \\
\hline East North Central & 18.27 & 13.75 & 6.68 & 8.32 & 10.60 \\
\hline West North Central & 9.11 & 3.44 & 2.11 & 3.37 & 8.44 \\
\hline South Atlantic & 17.93 & 35.30 & 15.02 & 12.86 & 15.07 \\
\hline East South Central & 6.29 & 9.37 & 1.34 & 1.51 & 3.51 \\
\hline West South Central & 8.97 & 13.15 & 20.52 & 8.04 & 15.54 \\
\hline Mountain & 7.46 & 2.08 & 10.13 & 4.63 & 11.75 \\
\hline Pacific & 12.33 & 6.58 & 30.65 & 40.86 & 25.53 \\
\hline (Total) & $(100.00)$ & $(100.00)$ & $(100.00)$ & $(100.00)$ & (100.00) \\
\hline \multicolumn{6}{|l|}{ Class of Worker (\%) } \\
\hline NA & 0.69 & 1.67 & 1.22 & 0.97 & 1.50 \\
\hline Self-Employed & 10.77 & 5.08 & 7.54 & 9.95 & 7.89 \\
\hline Private Sector & 74.18 & 75.37 & 81.63 & 77.88 & 72.18 \\
\hline Federal Government & 2.29 & 4.07 & 1.61 & 3.01 & 4.39 \\
\hline State Government & 4.41 & 5.32 & 2.53 & 4.10 & 5.49 \\
\hline \multirow{2}{*}{$\begin{array}{l}\text { Local Government } \\
\text { (Total) }\end{array}$} & 7.65 & 8.50 & 5.47 & 4.09 & 8.55 \\
\hline & (100.00) & $(100.00)$ & $(100.00)$ & $(100.00)$ & $(100.00)$ \\
\hline
\end{tabular}

Note: Results are based on the authors' calculations using the Current Population Survey (CPS) using survey sampling weights.

Table 1 shows that Hispanics and respondents of other race are relatively young with an average age of about 37, while $\mathrm{NH}$-whites are older with an average age of about 41 . The majority of Hispanics and Asians are foreign born (about $57 \%$ and $77 \%$, respectively) reflecting the relative recency of the bulk of Hispanic and Asian immigrants to the U.S. The sex ratios for Hispanics and blacks tend to be more imbalanced than the other groups. Most blacks were not married (i.e., 63\%) in contrast to the other groups. Asians have the highest level of educational achievement, while Hispanics have the lowest. Asians have the highest concentration in the Pacific region, while Hispanics are more concentrated in southern areas. For all of the racial/ethnic groups, the private sector is the most common class category. NH-whites and Asians are, however, slightly more likely than the other groups to be self-employed. 


\subsection{Unemployment Rates}

In regard to our dependent variable, Table 2 shows the unemployment rates from 2007 to 2013 for various demographic groups. As expected, unemployment rates for the native born, as well as the foreign born increased after 2007 as the Great Recession began to impact the labor force. Unemployment rates peaked in 2009 and 2010.

Table 2. Unemployment rate in percentages by demographic group, 2007 to 2013.

\begin{tabular}{ccccccccc}
\hline \multirow{2}{*}{ All } & & $\mathbf{2 0 0 7}$ & $\mathbf{2 0 0 8}$ & $\mathbf{2 0 0 9}$ & $\mathbf{2 0 1 0}$ & $\mathbf{2 0 1 1}$ & $\mathbf{2 0 1 2}$ & $\mathbf{2 0 1 3}$ \\
& Native born & 4.80 & 5.99 & 9.40 & 9.73 & 8.09 & 8.19 & 7.60 \\
& Foreign born & 4.46 & 5.91 & 9.88 & 9.93 & 9.20 & 8.23 & 7.12 \\
\hline \multirow{2}{*}{ NH-Whites } & Native born & 3.94 & 4.90 & 7.95 & 8.12 & 7.29 & 6.60 & 6.04 \\
& Foreign born & 3.81 & 5.00 & 7.92 & 7.55 & 7.56 & 7.07 & 6.49 \\
\hline \multirow{2}{*}{ Blacks } & Native born & 8.89 & 10.82 & 15.64 & 16.80 & 16.81 & 14.70 & 13.77 \\
& Foreign born & 6.24 & 7.55 & 11.67 & 12.45 & 12.55 & 11.30 & 10.67 \\
\hline \multirow{2}{*}{ Hispanics } & Native born & 6.82 & 8.76 & 13.30 & 13.98 & 13.26 & 11.62 & 10.80 \\
& Foreign born & 5.04 & 6.97 & 11.58 & 11.59 & 10.42 & 9.31 & 7.80 \\
\hline \multirow{2}{*}{ Asians } & Native born & 4.18 & 5.24 & 9.74 & 9.17 & 9.00 & 7.86 & 7.34 \\
& Foreign born & 3.12 & 3.77 & 7.04 & 7.29 & 6.74 & 5.89 & 5.01 \\
\hline \multirow{2}{*}{ Others } & Native born & 7.73 & 9.90 & 13.54 & 14.11 & 14.65 & 12.76 & 12.85 \\
& Foreign born & 5.14 & 6.28 & 10.47 & 8.90 & 7.85 & 7.27 & 6.13 \\
\hline \multirow{2}{*}{ Males } & Native born & 4.98 & 6.43 & 10.58 & 10.72 & 9.65 & 8.48 & 8.07 \\
& Foreign born & 4.18 & 5.77 & 10.23 & 10.13 & 8.92 & 7.57 & 6.64 \\
\hline \multirow{2}{*}{ Females } & Native born & 4.61 & 5.51 & 8.11 & 8.65 & 8.47 & 7.88 & 7.10 \\
& Foreign born & 4.89 & 6.12 & 9.38 & 9.66 & 9.59 & 9.12 & 7.76 \\
\hline
\end{tabular}

Note: Results are based on the authors' calculations using the CPS using survey sampling weights.

In 2007 at the beginning of the recession, the native born and the foreign born had approximately the same unemployment rate (i.e., $4.80 \%$ versus $4.46 \%$, respectively). As the recession began to unfold, Table 2 shows that the unemployment for immigrants began to slightly exceed the native born. Unemployment began decreasing as the recession subsided in 2011, but immigrants still exhibited rates that were a little higher. By 2013, however, unemployment rates for the native born and the foreign born returned to the 2007 situation of proximate parity (i.e., $7.60 \%$ versus $7.12 \%$, respectively).

Table 2 also shows the unemployment rates broken down by nativity and race/ethnicity. These results show the nativity differential with the net of race/ethnicity. Ironically, the overall pattern discussed above for immigrants as a whole is not really evident for any of the groups when considered separately. While there are some specific differences by race/ethnicity at the beginning of the recession, in general, the unemployment rate for each immigrant group was actually somewhat lower than for the corresponding native born group at the height of the recession. That is, for each racial/ethnic group, the unemployment rate for the foreign born was lower than for the native born in 2009 and 2010. This apparently contradictory pattern is likely driven by Hispanics because they are a large group that is mostly foreign born, and their unemployment rate rose substantially during the recession due to major downturns in certain sectors, such as construction, which employ many Hispanics [29-31].

Another notable result in Table 2 is the consistently high unemployment rate of native-born African Americans. They have a higher unemployment rate than any other group in each year, including foreign-born blacks. In general, the unemployment rate of foreign-born blacks more closely resembles the unemployment rate of foreign-born Hispanics than native-born blacks.

Table 2 also shows the unemployment rates by nativity broken down by gender (rather than race/ethnicity). At the beginning of the recession in 2007, native-born males, native-born females, 
immigrant males and immigrant females all had similar unemployment rates (i.e., 4.98\%, 4.18\%, 4.61\% and $4.89 \%$, respectively). The unemployment rates for each of these groups rose during the height of the recession, but slightly more for the foreign born.

In general, these basic demographic patterns are worthwhile to document. However, they do not provide a very clear assessment of the net effect of nativity status on the chances of being unemployed. More multivariate analysis is needed to further investigate this issue.

\subsection{Results for Logistic Regressions}

Tables 3 and 4 show the results for the logistic regression models of unemployment. Table 3 is for reference purposes and shows the effect of being foreign born on unemployment without any control variables. These results are substantively similar to the first row of Table 2 because they both refer to the overall bivariate association. Both Tables 2 and 3 indicate that the chances of being unemployed rose more for the foreign born during the height of the Great Recession.

Table 3. Logistic regression of unemployment without control variables, 2007 to 2013.

\begin{tabular}{cccccccc}
\hline & $\mathbf{2 0 0 7}$ & $\mathbf{2 0 0 8}$ & $\mathbf{2 0 0 9}$ & $\mathbf{2 0 1 0}$ & $\mathbf{2 0 1 1}$ & $\mathbf{2 0 1 2}$ & $\mathbf{2 0 1 3}$ \\
\hline Foreign Born & $0.9263^{* * *}$ & 0.9868 & $1.0571^{* * *}$ & 1.0230 & 1.0138 & 1.0056 & $0.9316^{* * *}$ \\
Native Born & REF & REF & REF & REF & REF & REF & REF \\
\hline
\end{tabular}

Note: ${ }^{* * *} p<0.001$; REF refers to the reference group.

Of more immediate interest are the multivariate results shown in Table 4, which refer to the net effect of being foreign born after including the control variables. The coefficients are shown after exponentiation, meaning that they indicate the percentage change in the odds ratio for a unit change in the independent variable (net of the other regressors in the model). When the coefficient is less than 1.0000, then the effect is negative (i.e., the odds ratio is reduced), while the effect is positive when the coefficient is greater than 1.0000 (i.e., the odds ratio is increased). Multiplying a coefficient by 1.0000 does not change the odds ratio (i.e., the independent variable has no effect).

Table 4. Logistic regression of unemployment with control variables, 2007 to 2013.

\begin{tabular}{|c|c|c|c|c|c|c|c|}
\hline & 2007 & 2008 & 2009 & 2010 & 2011 & 2012 & 2013 \\
\hline Foreign Born & $0.8444^{* * *}$ & $0.8759 * * *$ & $0.9079^{* * *}$ & $0.8407^{* * *}$ & $0.8711^{* * *}$ & $0.9159^{* * *}$ & $0.8742^{* * *}$ \\
\hline Native Born & REF & REF & REF & REF & REF & REF & REF \\
\hline NH-Whites & REF & REF & REF & REF & REF & REF & REF \\
\hline NH-Blacks & $1.9199^{* * *}$ & $1.9221^{* * *}$ & $1.7504^{* * *}$ & $1.8783^{* * *}$ & $2.0478^{* * *}$ & $1.9210^{* * *}$ & $1.9743^{* * *}$ \\
\hline Hispanics & $1.1513^{* * *}$ & $1.2176^{* * *}$ & $1.2230^{* * *}$ & $1.2403^{* * *}$ & $1.2281^{* * *}$ & $1.1784^{* * *}$ & $1.1895^{* * *}$ \\
\hline Asians & 0.9667 & 0.9462 & $1.1379^{* * *}$ & 1.0495 & $1.0802^{* *}$ & 0.9905 & 1.0002 \\
\hline Others & $1.6107^{* * *}$ & $1.6425^{* * *}$ & $1.4950^{* * *}$ & $1.4851^{* * *}$ & $1.7051^{* * *}$ & $1.5789 * * *$ & $1.8049^{* * *}$ \\
\hline Male & REF & REF & REF & REF & REF & REF & REF \\
\hline Female & $0.9445^{* * *}$ & $0.8670^{* * *}$ & $0.7569^{* * *}$ & $0.8024^{* * *}$ & $0.8925^{* * *}$ & $0.9740 *$ & $0.9130^{* * *}$ \\
\hline Age & $\mathrm{Y}$ & $\mathrm{Y}$ & $\mathrm{Y}$ & $\mathrm{Y}$ & $\mathrm{Y}$ & $\mathrm{Y}$ & $\mathrm{Y}$ \\
\hline Age 2 & $\mathrm{Y}$ & $\mathrm{Y}$ & $\mathrm{Y}$ & Y & $\mathrm{Y}$ & $Y$ & $\mathrm{Y}$ \\
\hline Education & $\mathrm{Y}$ & $\mathrm{Y}$ & $\mathrm{Y}$ & $\mathrm{Y}$ & $\mathrm{Y}$ & $\mathrm{Y}$ & $\mathrm{Y}$ \\
\hline Marital status & $\mathrm{Y}$ & $\mathrm{Y}$ & $\mathrm{Y}$ & Y & $\mathrm{Y}$ & $\mathrm{Y}$ & $\mathrm{Y}$ \\
\hline Region & $\mathrm{Y}$ & $\mathrm{Y}$ & $\mathrm{Y}$ & $\mathrm{Y}$ & $\mathrm{Y}$ & $\mathrm{Y}$ & $\mathrm{Y}$ \\
\hline Class of worker & Y & $\mathrm{Y}$ & Y & Y & Y & $\mathrm{Y}$ & $\mathrm{Y}$ \\
\hline
\end{tabular}

Table 4 shows that the net effect of being foreign born is consistently negative. After controlling for race/ethnicity, gender, age, region, education, marital status and class of work, then the foreign born actually had lower chances of being unemployed throughout the entire period of 2007 to 2013. 
For example, Table 4 shows that the coefficient for the foreign born in 2010 (during a high point in the recession) is 0.8407 , implying that the odds of an immigrant being unemployed in that year were about $16 \%$ lower than for a native-born worker. The other results in Table 4 indicate that the net effect of being foreign born is consistently lower during this period, ranging from $9 \%$ to $16 \%$ reduced odds. Thus, the higher unemployment rates observed for the foreign born during the Great Recession (as shown in Table 2) derive from their other observed characteristics (i.e., race/ethnicity, gender, age, region, education, marital status and class) rather than from their nativity per se. The negative effect of being foreign born is consistently observed in Table 4, but it is fairly random across the years regardless of the stage of this recessionary period.

Other notable results that are evident in Table 4 include the very large net effect for blacks indicating that they have substantially higher unemployment than expected based on their observed characteristics in comparison to whites. Although not quite as large, others and Hispanics also have higher unemployment. Conversely, the effect for women is significantly negative.

A further level of multivariate detail is next investigated in Tables 5 and 6, which shows the effects of nativity after breaking down by racial/ethnic group. That is, the same regression model is estimated separately for each of the racial/ethnic groups. This approach yields a higher level of precision and is akin to adding interaction terms by race/ethnicity into the model shown in Tables 3 and 4 . In the following, Table 5 shows the results for NH-whites; Table 6 shows the results for blacks; Table 7 shows the results for Hispanics; and Table 8 shows the results for Asians. Note, however, that in these tables, the reference group for the immigrant effect is the native born of the same race/ethnicity.

Table 5. Logistic regression of unemployment for non-Hispanic whites, 2007 to 2013.

\begin{tabular}{|c|c|c|c|c|c|c|c|}
\hline & 2007 & 2008 & 2009 & 2010 & 2011 & 2012 & 2013 \\
\hline Immigrants & $1.0911^{*}$ & $1.1451^{* * *}$ & $1.1551^{* * *}$ & 1.0295 & $1.1584^{* * *}$ & $1.1878^{* * *}$ & $1.2229^{* * *}$ \\
\hline Native-Born & REF & $\mathrm{REF}$ & REF & REF & REF & $\mathrm{REF}$ & REF \\
\hline Male & REF & REF & REF & REF & REF & REF & REF \\
\hline Female & $0.9217^{* * *}$ & $0.617^{* * *}$ & 0.7364 & $0.7742^{* * *}$ & $0.8788^{* * *}$ & $0.9545^{* *}$ & $0.8803^{* * *}$ \\
\hline Age & $\mathrm{Y}$ & $\mathrm{Y}$ & $\mathrm{Y}$ & $\mathrm{Y}$ & $\mathrm{Y}$ & $\mathrm{Y}$ & $\mathrm{Y}$ \\
\hline Age 2 & $\mathrm{Y}$ & $\mathrm{Y}$ & $\mathrm{Y}$ & $\mathrm{Y}$ & $\mathrm{Y}$ & $\mathrm{Y}$ & $\mathrm{Y}$ \\
\hline Education & $\mathrm{Y}$ & $\mathrm{Y}$ & $\mathrm{Y}$ & $\mathrm{Y}$ & $\mathrm{Y}$ & $\mathrm{Y}$ & $\mathrm{Y}$ \\
\hline Marital status & $\mathrm{Y}$ & $\mathrm{Y}$ & $\mathrm{Y}$ & $\mathrm{Y}$ & $\mathrm{Y}$ & $\mathrm{Y}$ & $\mathrm{Y}$ \\
\hline Region & $\mathrm{Y}$ & $\mathrm{Y}$ & $\mathrm{Y}$ & $\mathrm{Y}$ & $\mathrm{Y}$ & $\mathrm{Y}$ & $\mathrm{Y}$ \\
\hline Class of worker & $\mathrm{Y}$ & $\mathrm{Y}$ & $\mathrm{Y}$ & $\mathrm{Y}$ & $\mathrm{Y}$ & $\mathrm{Y}$ & $\mathrm{Y}$ \\
\hline
\end{tabular}

Note: ${ }^{*} p<0.05 ;{ }^{* *} p<0.01 ;{ }^{* * *} p<0.001$.

Table 6. Logistic regression of unemployment for blacks, 2007 to 2013.

\begin{tabular}{|c|c|c|c|c|c|c|c|}
\hline & 2007 & 2008 & 2009 & 2010 & 2011 & 2012 & 2013 \\
\hline Immigrants & $0.8384^{* *}$ & $0.8040^{* * *}$ & $0.8583 * *$ & $0.7863^{* * *}$ & $0.8180^{* * *}$ & $0.8319^{* * *}$ & $0.8400^{* * *}$ \\
\hline Native-Born & REF & REF & REF & REF & REF & REF & REF \\
\hline Male & REF & REF & REF & REF & REF & REF & REF \\
\hline Female & $0.8323^{* * *}$ & $0.7583^{* * *}$ & $0.6889^{* * *}$ & $0.7379 * * *$ & $0.7758^{* * *}$ & $0.8360^{* * *}$ & $0.8910^{* * *}$ \\
\hline Age & $\mathrm{Y}$ & $\mathrm{Y}$ & $\mathrm{Y}$ & $\mathrm{Y}$ & $\mathrm{Y}$ & $\mathrm{Y}$ & $\mathrm{Y}$ \\
\hline Age 2 & $\mathrm{Y}$ & $\mathrm{Y}$ & $\mathrm{Y}$ & $Y$ & $\mathrm{Y}$ & $Y$ & Y \\
\hline Education & $\mathrm{Y}$ & $\mathrm{Y}$ & $\mathrm{Y}$ & $\mathrm{Y}$ & $\mathrm{Y}$ & $\mathrm{Y}$ & Y \\
\hline Marital status & $\mathrm{Y}$ & $\mathrm{Y}$ & $\mathrm{Y}$ & $\mathrm{Y}$ & $\mathrm{Y}$ & $\mathrm{Y}$ & Y \\
\hline Region & $\mathrm{Y}$ & $\mathrm{Y}$ & $\mathrm{Y}$ & $\mathrm{Y}$ & $\mathrm{Y}$ & $\mathrm{Y}$ & Y \\
\hline Class of worker & $\mathrm{Y}$ & $\mathrm{Y}$ & $\mathrm{Y}$ & $\mathrm{Y}$ & $\mathrm{Y}$ & $\mathrm{Y}$ & $\mathrm{Y}$ \\
\hline
\end{tabular}


Table 7. Logistic regression of unemployment for Hispanics, 2007 to 2013.

\begin{tabular}{cccccccc}
\hline & $\mathbf{2 0 0 7}$ & $\mathbf{2 0 0 8}$ & $\mathbf{2 0 0 9}$ & $\mathbf{2 0 1 0}$ & $\mathbf{2 0 1 1}$ & $\mathbf{2 0 1 2}$ & $\mathbf{2 0 1 3}$ \\
\hline Immigrants & $0.7095^{* * *}$ & $0.7662^{* * *}$ & $0.8048^{* * *}$ & $0.7539^{* * *}$ & $0.7640^{* * *}$ & $0.8263^{* * *}$ & $\begin{array}{c}0.7323^{* * *} \\
\text { REF }\end{array}$ \\
\hline Native-Born & REF & REF & REF & REF & REF & REF & REF \\
Male & REF & REF & REF & REF & REF & REF & REF \\
Female & $1.1683^{* * *}$ & 1.0153 & $0.8840^{* * *}$ & $0.9487^{*}$ & $1.0722^{* *}$ & $1.1718^{* * *}$ & $1.0659^{*}$ \\
\hline Age & $\mathrm{Y}$ & $\mathrm{Y}$ & $\mathrm{Y}$ & $\mathrm{Y}$ & $\mathrm{Y}$ & $\mathrm{Y}$ & $\mathrm{Y}$ \\
Age2 & $\mathrm{Y}$ & $\mathrm{Y}$ & $\mathrm{Y}$ & $\mathrm{Y}$ & $\mathrm{Y}$ & $\mathrm{Y}$ & $\mathrm{Y}$ \\
Education & $\mathrm{Y}$ & $\mathrm{Y}$ & $\mathrm{Y}$ & $\mathrm{Y}$ & $\mathrm{Y}$ & $\mathrm{Y}$ & $\mathrm{Y}$ \\
Marital status & $\mathrm{Y}$ & $\mathrm{Y}$ & $\mathrm{Y}$ & $\mathrm{Y}$ & $\mathrm{Y}$ & $\mathrm{Y}$ & $\mathrm{Y}$ \\
Region & $\mathrm{Y}$ & $\mathrm{Y}$ & $\mathrm{Y}$ & $\mathrm{Y}$ & $\mathrm{Y}$ & $\mathrm{Y}$ & $\mathrm{Y}$ \\
Class of worker & $\mathrm{Y}$ & $\mathrm{Y}$ & $\mathrm{Y}$ & $\mathrm{Y}$ & $\mathrm{Y}$ & $\mathrm{Y}$ & $\mathrm{Y}$ \\
\hline
\end{tabular}

Table 8. Logistic regression of unemployment for Asians, 2007 to 2013.

\begin{tabular}{|c|c|c|c|c|c|c|c|}
\hline & 2007 & 2008 & 2009 & 2010 & 2011 & 2012 & 2013 \\
\hline Immigrants & 0.9834 & 0.9782 & 0.9485 & 1.0116 & 0.9353 & 0.995 & 0.9339 \\
\hline Native-Born & REF & REF & REF & REF & REF & REF & REF \\
\hline Male & REF & REF & REF & REF & REF & REF & REF \\
\hline Female & 1.0267 & $0.8416^{*}$ & $0.7886^{* * *}$ & $0.8245^{* * *}$ & 0.9787 & 0.9712 & $0.8561^{* *}$ \\
\hline Age & $\mathrm{Y}$ & $\mathrm{Y}$ & $\mathrm{Y}$ & Y & $\mathrm{Y}$ & Y & $\mathrm{Y}$ \\
\hline Age2 & $\mathrm{Y}$ & $\mathrm{Y}$ & $\mathrm{Y}$ & Y & Y & Y & $\mathrm{Y}$ \\
\hline Education & $\mathrm{Y}$ & $\mathrm{Y}$ & $\mathrm{Y}$ & $\mathrm{Y}$ & $\mathrm{Y}$ & $\mathrm{Y}$ & $\mathrm{Y}$ \\
\hline Marital status & $\mathrm{Y}$ & $\mathrm{Y}$ & $\mathrm{Y}$ & Y & Y & Y & $\mathrm{Y}$ \\
\hline Region & $\mathrm{Y}$ & $\mathrm{Y}$ & $\mathrm{Y}$ & Y & Y & Y & $\mathrm{Y}$ \\
\hline Class of worker & $\mathrm{Y}$ & Y & $\mathrm{Y}$ & Y & Y & Y & Y \\
\hline
\end{tabular}

The findings in these tables indicate that interactions by race/ethnicity do seem to be evident. Three basic patterns emerge in regard to the odds of being unemployed. First, in almost all of the years, $\mathrm{NH}$-white immigrants have significantly higher odds of unemployment (ranging from $9 \%$ to $22 \%$ ) compared to $\mathrm{NH}$-whites that are native born. Second, throughout this period, black immigrants and Hispanic immigrants have substantially lower unemployment compared to their native born counterparts. In regard to Asians, the nativity effect is not statistically significant; no difference between immigrants and the native born is discernable with the net of the control variables.

In regard to gender, some variation in unemployment by race/ethnicity is apparent. Among whites and blacks, women have lower chances of being unemployed than their corresponding male workers throughout this period. Among Asians, the same is mostly true, except that the gender differential is not statistically significant in a few of the years. The group that stands out most is Hispanics for whom women have slightly higher unemployment than Hispanic men at the start and the end of the recession, but significantly lower unemployment during the height of the recession in 2009 and 2010.

\section{Summary and Discussion}

Our results indicate that unemployment rates increased for all demographic groups during the Great Recession, particularly at its height in 2009 and 2010. Relative to that time period, the unemployment rates for all demographic groups also declined by 2013 as the recession came to an end. Nonetheless, unemployment rates in 2013 still remained above their levels in 2007 at the start of the recession for all demographic groups. 
The unemployment rate of the foreign born did not differ much from the native born at the start of the Great Recession. At its height, however, the unemployment rate of the foreign born came to exceed the native born. This latter differential stems largely from the observed characteristics of immigrants, including their race/ethnicity, gender, age, region, education, marital status and class. After controlling for those covariates, the net effect of being foreign born is consistently lower, ranging from a $9 \%$ to $16 \%$ reduced odds during different years of the Great Recession. Rather than being an intrinsic disadvantage in regard to unemployment, immigrants as an overall group appear to be less likely to be unemployed when compared to the native born with similar demographic and socioeconomic characteristics.

This conclusion is partly, but not entirely confirmed in more detailed estimates that are broken down by specific racial/ethnic group. With the net of observed characteristics, foreign-born blacks have significantly less unemployment than native-born blacks, and foreign-born Hispanics have substantially less unemployment than native-born Hispanics. The two exceptions are Asians (for whom nativity has no statistically significant effect) and whites (for whom immigrants actually have slightly higher chances of being unemployed than comparable native born). Native born Asians are mostly second generation who are well-known for having high levels of educational achievement, including in dimensions not measured (i.e., fields of study, such as majoring in science, technology, engineering or math; college prestige or Carnegie classification; whether the college is in the U.S. or overseas) in our analysis [20,32], which may help to explain why the Asian native born does as well as the Asian foreign born in terms of unemployment. Regarding white immigrants, they may possibly be less economically selected and motivated than the immigrants of other racial/ethnic groups; white immigration (i.e., from Canada and Europe) may perhaps be more associated with social networks, existing family ties and marital relations with American citizens. White immigrants are a particularly understudied group, and additional research on them is warranted.

Our analysis also investigated other demographic effects when the immigration effect is held constant as an overall group. In general, after controlling for observed characteristics, substantially higher unemployment rates are observed among blacks, others and Hispanics compared to whites. Native-born blacks have particularly higher chances of being unemployed. Many persons who identify as others could also be considered to be immigrant Hispanics [33]. On the other hand, the differential between Asians and whites is usually not statistically significant. Women as a group have less unemployment than men as a group.

Overall, our results suggest the particular significance of Hispanics (and possibly others) in affecting the patterns of unemployment during the Great Recession. As noted above, the higher overall unemployment rate of the foreign born relative to the native born in 2009 and 2010 was likely driven by Hispanics because they are a large group that is mostly foreign born, and their unemployment rate rose substantially during the recession due to major downturns in certain sectors, such as construction, that employ many Hispanics [14,30,31]. Hispanic migration also differs somewhat from the other groups due the close geographic proximity of the U.S. to Mexico, so that patterns of circular and return migration are quite feasible [14,34].

Despite suffering substantial unemployment during the height of the Great Recession, the irony is that the net effect of being foreign born (i.e., after controlling for observed characteristics) for Hispanics was actually lower than for any of the other racial/ethnic groups in 2009 and 2010. This apparent paradox might derive from the greater selectivity (the net of observed characteristics) of Hispanic workers who were in the U.S. at the start of the recession. That is, they may have been those who were the most skilled or well-matched in their jobs in the U.S. due to continuous return migration of Hispanics who were less successful here [35].

The other indicator of the uniqueness of Hispanic immigration is that Hispanics are the only group for whom the net effect of being female is positive for most of these years, except during the height of the Great Recession in 2009 and 2010. The reasons for this are unclear, and gender differentials in unemployment by race/ethnicity certainly merit further research. We speculate that this pattern 
may arise because Hispanic families tend to have lower incomes and are especially dependent on dual earners due to their higher family sizes. At the same time, in contrast to black men, Hispanic men have higher levels of employment.

In general, the overall female effect is probably negative for most other groups. Some researchers have even referred to the Great Recession as a "mancession" because the industries in which women are more heavily concentrated (i.e., education, health and social services) were less heavily impacted by the economic downturn than were industries in which men are more heavily concentrated (i.e., manufacturing and construction). Moreover, many women are probably more able than men to withdraw from labor force participation when suitable employment is unavailable. The latter circumstance may help to account for why the female effect on employment is negative even for Hispanics at the height of the Great Recession in 2009 and 2010 (i.e., when job loss in the U.S. was at a record high).

In regard to immigrants as an overall group, our results are largely inconsistent with the view that the foreign born are especially more prone to unemployment. Immigrants are prone to unemployment when they have lower levels of education and work experience, but the same applies to the native born, as well. One reason for our findings, as we have already discussed, is the pattern of return migration for immigrants who are less successful. While we have described this pattern as being particularly pronounced among Hispanics due to geographic propinquity, it may also apply at least to a lesser extent for the other racial/ethnic groups, as well (e.g., [36]).

Another related factor is visa enforcement, which has likely become somewhat stricter since 9/11. Immigrants who are not permanent residents or citizens of the U.S. typically need to have a job in order to secure their visa to stay in the U.S. Those who were in the U.S. when answering the CPS surveys usually had to have jobs in order to remain here. Those who lost their jobs during the Great Recession (and could not find other employment) might have already left the country. In addition, many Hispanic immigrants do not have an authorized visa to stay in the U.S. During the recession, many undocumented Hispanic immigrants might have been unable to secure a job and, thus, returned to Mexico. This could further reduce unemployment in general for immigrants during the recession.

In addition, visa holders and unauthorized immigrants often have less accessibility to social welfare benefits and unemployment insurance (being ineligible or even just less aware of American bureaucracy). When immigrants were laid off at some point during the recession, they might have been more motivated than the native born to take lower-paying jobs. While immigrants were more willing to take lower-paying jobs, the native born were more likely to engage in a longer job search while being subsidized by unemployment insurance benefits. For all of these reasons, unemployment among the foreign born often seems to be less likely than among the native born.

\section{Conclusions}

The observed unemployment rate for the foreign born was greater than for the native born during the height of the Great Recession. However, after controlling for observed characteristics, including race/ethnicity, gender, age, region, education, marital status and class, the chances of being unemployed were actually lower for the foreign born overall compared to the native born overall. This advantage is especially evident among blacks and Hispanics, though not among whites and Asians. The view that immigrants are intrinsically disadvantaged in the labor market in regard to employment may be exaggerated by the selectivity of many immigrants and possibly their greater motivation to be employed, especially in the case of blacks and Hispanics.

For those groups in particular and for many individuals in other groups in general, jobs are one of the important factors for immigrating to a destination country in the first place [37,38]. Villarreal [31] thus argues that the Great Recession has reduced migration outflows from Mexico to the U.S. especially among less educated Mexican men. Immigrants are also motivated to stay employed so that they can continue to send remittances back to their family relations still residing in their place of origin $[39,40]$. 
For all of these reasons, immigrants seem to more rapidly adjust to the economic opportunities that are actually available to them in the U.S. labor market. In our results, that pattern seems most evident for blacks and Hispanics. For white and Asian immigrants, on the other hand, perhaps they can be somewhat choosier in searching longer for jobs that they feel are more suitable to them. White and Asian immigrants generally have higher incomes (due to having higher levels of education, which is an observed covariate in our analysis), which allows them to search longer for alternative employment after becoming unemployed.

While the Great Recession obviously had severe short-term consequences for unemployment for all demographic groups, our findings underscore how this economic outcome is a little different from wages and earnings. Almost all individuals would prefer, ceteris paribus, a higher wage. Being paid a lower wage is generally a clear disadvantage. Black and Hispanic immigrants generally have lower wages than white and Asian immigrants. However, our results indicate that white and Asian immigrants have a higher chance of being unemployed than their native-born counterparts, whereas black and Hispanic immigrants have a lower chance of being unemployed relative to their native-born counterparts with equivalent observed characteristics. One could argue that white and Asian immigrants can afford to be unemployed longer and to be choosier in accepting new employment than black and Hispanic immigrants. To the extent that unemployment represents an investment of foregone earnings at a lower wage so as to look for a better job at a higher wage, unemployment may not be quite as much of an absolute bad as is having a lower wage in itself. Relatedly, women generally have lower wages than men [41], but women seem to have lower unemployment.

Our study has shed some light on the short-term relations between immigration, race/ethnicity, gender and social inequality in regard to unemployment in the U.S. labor market. Future research will be needed to assess demographic differentials in the possible long-term consequences of the Great Recession. For example, racial/ethnic differentials in wages and inequality in long-term earnings may be affected by differential unemployment experiences. Future research might also investigate other related datasets, such as the American Community Survey, which has other possible control variables, such as a measure of English language proficiency.

Author Contributions: Sharron Xuanren Wang conceived of the overall analysis, obtained appropriate data, specified the statistical models, did the computer programming, and wrote the first draft of the paper. Especially after the first stage of reviews, Arthur Sakamoto helped to refine the statistical models, sharpened the theoretical focus of the analysis, and revised and copy-edited the text of the paper.

Conflicts of Interest: The authors declare no conflict of interest.

\section{References}

1. Elsby, Michael W., Bart Hobijn, and Aysegul Sahin. "The Labor Market in the Great Recession." Working Paper No. w15979, National Bureau of Economic Research (NBER), Cambridge, MA, USA, 2010.

2. Bureau of Labor Statistics. "The Current Population Survey." Available online: http://data.bls.gov/ timeseries/LNU04000000?years_option=all_years\&periods_option=specific_periods\&periods=Annual+ Data (accessed on 15 June 2015).

3. Kochhar, Rakesh, C. Soledad Espinoza, and Rebecca Hinze-Pifer. "After the Great Recession: Foreign Born Gain Jobs; Native Born Lose Jobs." Pew Resarch Center, 2010. Available online: http:/ /www.pewhispanic. org/2010/10/29/after-the-great-recession-brforeign-born-gain-jobs-native-born-lose-jobs / (accessed on 12 January 2015).

4. Farber, Henry S. "Job loss in the Great Recession: Historical perspective from the displaced workers survey, 1984-2010." Working Paper No. 17040, NBER, Cambridge, MA, USA, 2011.

5. Brand, Jennie E. "The Far-Reaching Impact of Job Loss and Unemployment." Annual Review of Sociology 41 (2015): 359-75. [CrossRef] [PubMed]

6. Newman, Katherine S. Falling from Grace: The Experience of Downward Mobility in the American Middle Class. New York: Vintage Books, 1988.

7. Dooley, David, Jonathan Fielding, and Lennart Levi. "Health and Unemployment." Annual Review of Public Health 17 (1996): 449-65. [CrossRef] [PubMed] 
8. Vinokur, Amiram D., Richard H. Price, and Robert D. Caplan. "Hard times and Hurtful Partners: How Financial Strain Affects Depression and Relationship Satisfaction of Unemployed Persons and Their Spouses." Journal of Personality and Social Psychology 71 (1996): 166-79. [CrossRef] [PubMed]

9. Price, Richard H., Jin Nam Choi, and Amiram D. Vinokur. "Links in the Chain of Adversity Following Job Loss: How Financial Strain and Loss of Personal Control Lead to Depression, Impaired Functioning, and Poor Health." Journal of Occupational Health Psychology 7 (2002): 302-12. [CrossRef] [PubMed]

10. Wilson, Franklin D., Marta Tienda, and Lawrence Wu. "Race and Unemployment: Labor Market Experiences of Black and White Men, 1968-1988." Work and Occupations 22 (1995): 245-70. [CrossRef]

11. Chiswick, Barry R., and Michael E. Hurst. "The Employment, Unemployment and Unemployment Compensation Benefits of Immigrants." Discussion Paper No. 129, The Institute for the Study of Labor (IZA) Bonn, Germany, 2000. Available online: http:/ /ssrn.com/abstract=224237 (accessed on 3 Feburary 2016).

12. Kalleberg, Arne L. Good Jobs, Bad Jobs. New York: Russell Sage Foundation, 2012.

13. Katz, Lawrence. "Long-term Unemployment in the Great Recession." Testimony for the Joint Economic Committee, US Congress, April 2010, vol. 29.

14. Laird, Jennifer. "Unemployment among Mexican immigrant men in the United States, 2003-2012." Social Science Research 49 (2015): 202-16. [CrossRef] [PubMed]

15. Leicht, Kevin T. "Broken down by race and gender? Sociological explanations of new sources of earnings inequality." Annual Review of Sociology 34 (2008): 237-55. [CrossRef]

16. Toossi, Mitra. "Labor force projections to 2020: A more slowly growing workforce." Monthly Labor Review 135 (2012): 43-64.

17. Terrazas, Aaron. "The Economic Integration of Immigrants in the United States: Long- and Short-Term Perspectives." Migration Policy Institute, 2011. Available online: http:/ /www.migrationpolicy.org/research/ economic-integration-immigrants-united-states (accessed on 15 January 2015).

18. Sa, Filipa. "Does Employment Protection Help Immigrants? Evidence from European Labor Markets." Labor Economics 18 (2011): 624-42. [CrossRef]

19. Zeng, Zhen, and Yu Xie. "Asian-Americans' Earnings Disadvantage Reexamined: The Role of Place of Education." American Journal of Sociology 109 (2004): 1075-108. [CrossRef]

20. Kim, Chang Hwan, and Arthur Sakamoto. "Have Asian American men achieved labor market parity with white men? " American Sociological Review 75 (2010): 934-57. [CrossRef]

21. Hirsch, Boris, and Elke J. Jahn. "Is There Monopsonistic Discrimination Against Immigrants? First Evidence from Linked Employer-Employee Data." IZA Discussion Paper No. 6472, The Institute for the Study of Labor, Bonn, Germany, 2012. Available online: http://ssrn.com/abstract=2039658 (accessed on 15 January 2015).

22. Greenwood, Michael J., and John M. McDowell. "The Factor Market Consequences of U.S. Immigration." Journal of Economic Literature 24 (1986): 1738-72.

23. Gilbert, Dennis. The American Class Structure in an Age of Growing Inequality. Thousand Oaks: SAGE Publications, Inc., 2014.

24. Friedberg, Rachel M., and Jennifer Hunt. “The Impact of Immigrants on Host Country Wages, Employment and Growth." The Journal of Economic Perspectives 9 (1995): 23-44.

25. Linton, April. "Immigration and the Structure of Demand: Do Immigrants Alter the Labor Market Composition of U.S. Cities? " International Migration Review 36 (2006): 58-88. [CrossRef]

26. Chellaraj, Gnanaraj, Keith Maskus, and Aaditya Mattoo. "The Contribution of Skilled Immigration and International Graduate Students to U.S. Innovation." World Bank Policy Research Working Paper No. 3588, World Bank, Washington, 2005. Available online: http://ssrn.com/abstract=744625 (accessed on 15 January 2015).

27. Borjas, George J., Jeffrey Grogger, and Gordon H. Hanson. "Immigration and the Economic Status of African-American Men." Economica 77 (2010): 255-82. [CrossRef]

28. Miriam King, Steven Ruggles, J. Trent Alexander, Sarah Flood, Katie Genadek, Matthew B. Schroeder, Brandon Trampe, and Rebecca Vick. Integrated Public Use Microdata Series, Current Population Survey, Version 3.0. [Machine-readable database]; Minneapolis: University of Minnesota, 2010.

29. Orrenius, Pia M., and Madeline Zavodny. "Immigrants' Employment Outcomes Over the Business Cycle." IZA Discussion Paper No. 5354, The Institute for the Study of Labor, Bonn, Germany, 2010. Available online: http:/ / ssrn.com/abstract=1723992 (accessed on 14 March 2016). 
30. Liu, Cathy Yang, and Jason Edwards. "Immigrant employment through the Great Recession: Individual characteristics and metropolitan contexts." The Social Science Journal 52 (2015): 405-14. [CrossRef]

31. Villarreal, Andrés. "Explaining the decline in Mexico-US migration: The effect of the Great Recession." Demography 51 (2014): 2203-28. [CrossRef] [PubMed]

32. Sakamoto, Arthur, Kimberly A. Goyette, and Chang Hwan Kim. "Socioeconomic attainments of Asian Americans." Annual Review of Sociology 35 (2009): 255-76. [CrossRef]

33. Choi, Kate H., Arthur Sakamoto, and Daniel Powers. "Who is Hispanic? Hispanic identity among African Americans, Asian Americans, others, and whites." Sociological Inquiry 78 (2008): 335-71. [CrossRef]

34. Massey, Douglas S., and Kristin E. Espinosa. "What's driving Mexico-US migration? A theoretical, empirical, and policy analysis." American Journal of Sociology 102 (1997): 939-99. [CrossRef]

35. Rendall, Michael S., Peter Brownell, and Kups Sarah. "Declining Return Migration from the United States to Mexico in the late-2000s recession: A research note." Demography 48 (2011): 1049-58. [CrossRef] [PubMed]

36. Suzuki, Masao. "Success story? Japanese immigrant economic achievement and return migration, 1920-1930." The Journal of Economic History 55 (1995): 889-901. [CrossRef]

37. Todaro, Michael P. "A Model of Labor Migration and Urban Unemployment in Less Developed Countries." The American Economic Review 59 (1969): 138-48.

38. Cerrutti, Marcela, and Douglas S. Massey. "On the Auspices of Female Migration from Mexico to the United States." Demography 38 (2001): 187-200. [CrossRef] [PubMed]

39. Dustmann, Christian, and Josep Mestres. "Remittances and Temporary Migration." Journal of Development Economics 92 (2010): 62-70. [CrossRef]

40. Dustmann, Christian, Albrecht Glitz, and Thorsten Vogel. "Employment, Wages, and the Economic Cycle: Differences between Immigrants and Natives." European Economic Review 54 (2010): 1-17. [CrossRef]

41. Blau, Francine D., and Lawrence M. Kahn. "Gender differences in pay." Working Paper No. w7732, NBER, Cambridge, MA, USA, 2000.

(C) 2016 by the authors; licensee MDPI, Basel, Switzerland. This article is an open access article distributed under the terms and conditions of the Creative Commons Attribution (CC-BY) license (http://creativecommons.org/licenses/by/4.0/). 